\title{
WHY DO BOOMERS PLAN TO WORK SO LONG?
}

\author{
Gordon B.T. Mermin, Richard W. Johnson, and Dan Murphy*
}

CRR WP 2006-19

Released: November 2006

Draft Submitted: October 2006

\author{
Center for Retirement Research at Boston College \\ 258 Hammond Street \\ Chestnut Hill, MA 02467 \\ Tel: 617-552-1762 Fax: 617-552-0191 \\ www.bc.edu/crr
}

\begin{abstract}
* Gordon B.T. Mermin is a research associate at the Urban Institute. Richard W. Johnson is a senior research associate at the Urban Institute. Dan Murphy is a research assistant at the Urban Institute. The research reported herein was performed pursuant to a grant from the U.S. Social Security Administration (SSA) funded as part of the Retirement Research Consortium. The findings and conclusions expressed are solely those of the authors and do not represent the views of SSA, any agency of the Federal Government, Boston College, or the Urban Institute, members of its board, or its sponsors.

(C) 2006, by Gordon B.T. Mermin, Richard W. Johnson, and Dan Murphy. All rights reserved. Short sections of text, not to exceed two paragraphs, may be quoted without explicit permission provided that full credit, including (C) notice, is given to the source.
\end{abstract}




\title{
About the Center for Retirement Research
}

The Center for Retirement Research at Boston College, part of a consortium that includes parallel centers at the University of Michigan and the National Bureau of Economic Research, was established in 1998 through a grant from the Social Security Administration. The goals of the Center are to promote research on retirement issues, to transmit new findings to the policy community and the public, to help train new scholars, and to broaden access to valuable data sources. Through these initiatives, the Center hopes to forge a strong link between the academic and policy communities around an issue of critical importance to the nation's future.

\author{
Center for Retirement Research at Boston College \\ 258 Hammond Street \\ Chestnut Hill, MA 02467 \\ phone: 617- 552- 1762 fax: 617- 552- 0191 \\ e-mail: crr@bc.edu \\ www.bc.edu/crr
}

\author{
Affiliated Institutions: \\ American Enterprise Institute \\ The Brookings Institution \\ Center for Strategic and International Studies \\ Massachusetts Institute of Technology \\ Syracuse University \\ Urban Institute
}




\begin{abstract}
Recent changes in retirement trends and patterns have raised questions about the likely retirement behavior of baby boomers, the large cohort born between 1946 and 1964. This study compares the retirement expectations of workers ages 51 to 56 in 2004 (who were born between 1948 and 1953, the leading edge of the baby boom) and 1992 (born between 1936 and 1941). Data come from the Health and Retirement Study.
\end{abstract}

Work expectations increased significantly over the period. Between 1992 and 2004, the mean expected probability of working full-time past age 62 among workers ages 51 to 56 increased from 47 percent to 51 percent. The increase was even more rapid for the expected mean probability of full-time work after age 65, which grew from 27 percent to about 33 percent over the period. Controlling for other factors, self employment, education, and earnings increased work expectations at older ages, while defined benefit pension coverage, employer-sponsored retiree health benefits, and household wealth reduced expectations.

Lower rates of retiree health insurance offers from employers, higher levels of educational attainment, and lower rates of defined benefit pension coverage accounted for most of the increase between 1992 and 2004 in expected work probabilities after ages 62 and 65. These trends suggest that the boomers will remain at work longer than the previous generation. The recent uptick in average retirement ages appears to be the leading edge of a new long-term trend. Lengthier careers will likely promote economic growth, increase government revenue, and improve individual financial security at older ages. 


\section{Introduction}

The age at which older adults retire affects economic well-being in later life and the relative size of the dependent population. By working longer, people can accumulate more Social Security wealth, employer-sponsored pension wealth, and other savings, while reducing the number of years over which their retirement wealth must finance consumption needs.

Encouraging older people to work longer would also increase the total production of goods and services, enhancing living standards and raising government revenues that fund services for both the young and old.

Recent changes in retirement trends and patterns have raised questions about the likely retirement behavior of baby boomers, the large cohort born between 1946 and 1964. Average male retirement ages declined steadily throughout most of the last century, but this trend appears to have ended about 20 years ago, and may have now reversed. Many older people now move from full-time work in career jobs to part-time work in jobs that serve as bridges to retirement, rather than leaving the labor force directly from career employment. Because the reasons behind these changes are not well understood, it is unclear whether the boomers will continue the recent trend toward later retirement or revert to the longer-term trend of earlier retirement. Better information is needed on the boomers' retirement expectations to assess how quickly they will leave the labor force and the likely economic and social impact.

This study examines recent changes in retirement expectations and the factors that may account for differences over time. Using nationally representative data from the Health and Retirement Study (HRS), the analysis compares expected probabilities of working full-time past ages 62 and 65 for 51- to 56-year-old workers in 1992 and 2004. The study models retirement expectations for both generations to examine the key factors influencing anticipated labor supply 
at older ages, and then uses the estimated regression coefficients to identify the forces that appear to drive generational differences in retirement expectations.

\section{Consequences of Retirement Decisions}

Baby boomers’ retirement decisions will have important implications for public and private retirement systems, the economy, and their own financial security. The first of the boomers will reach the Social Security early eligibility age in 2008, and many boomers will leave the labor force in the following decades. In fact, the Social Security actuaries predict the number of workers per retiree will decrease from 3.3 to 2.2 over the next 25 years, and the Social Security system will begin to run a deficit in 2017, becoming insolvent by 2040 (Board of Trustees 2006). Medicare already pays more in benefits than it collects in taxes and will deplete its Hospital Insurance trust fund by 2017, according to current projections (Medicare Board of Trustees 2006). The same demographic challenges confront the employer-sponsored defined benefit (DB) pension system. The Pension Benefit Guarantee Corporation (2005) estimates that the private defined benefit pension plans it insures are underfunded by $\$ 650$ billion, and the National Association of State Retirement Administrators (2006) estimates state and local pension plans are underfunded by $\$ 337$ billion.

The retirement of the baby boomers is also likely to significantly reduce labor force growth. According to our calculations from Bureau of Labor Statistics projections (Toosi 2002), the labor force will grow by only 0.7 percent per year over the next two decades, down from 1.4 percent per year over the previous 20 years. The slowdown in the average annual growth rate will be even more striking for the prime-age labor force (ages 25 to 54), falling from 2.1 percent over the last two decades to just 0.3 percent for the next two decades. Some analysts suggest that slow labor force growth could result in worker shortages or skill gaps that impede economic 
progress (Aspen Institute 2003; Judy 1999; Nyce and Schieber 2001), although others are skeptical (Cappelli 2005).

In addition to economy-wide impacts, the boomers' retirement decisions will affect their own retirement incomes. Those who delay retirement avoid early retirement reductions to their Social Security and DB pension benefits, accumulate more Social Security and pension credits and other savings, and reduce the number of retirement years that they must fund. By working until age 67 instead of retiring at age 62, for example, a typical worker could gain about $\$ 10,000$ in annual income at age 75, net of federal income taxes and health insurance premiums (Butrica et al. 2005).

\section{Retirement Trends}

Retirement ages declined steadily for men throughout most of the $20^{\text {th }}$ century. In 1870 , 84 percent of men ages 65 and over participated in the labor force (Costa 1998). However, the participation rate had fallen to 46 percent by 1950 and to 16 percent in 1990. Participation rates for women ages 65 and over declined slightly between 1950 and 1990, only falling from 10 percent to 9 percent, as the movement of women into the labor force after World War II mostly offset the general trend towards earlier retirement (Toosi 2002).

Recent economic, social, and demographic trends suggest that boomers may work longer than the previous generation. Improved health and declines in physical job demands leave older people better able to work today than in the past. Between 1982 and 2004, the share of adults ages 55 to 64 reporting fair or poor health declined from 27 percent to 18 percent (National Center for Health Statistics 2006). Many studies have concluded that poor health is an important predictor of early retirement (Blau and Gilleskie 2001; Bound et al. 1998; Dwyer and Mitchell 1999; McGarry 2003). Additionally, the share of workers in physically demanding jobs, defined 
as those that require frequent lifting or carrying of objects weighing more than 25 pounds, declined from 20 percent in 1950 to 8 percent in 1996 (Steuerle, Spiro, and Johnson 1999). Increases in educational attainment mirror the decline in jobs in our knowledge-based economy that require physical effort. Between 1960 and 2004 the share of people over age 25 with some college education increased from 9 percent to 25 percent, while the share completing only high school declined from 58 percent to 19 percent (U.S. Census Bureau 2005).

Recent Social Security changes increase work incentives at older ages. The normal retirement age for full Social Security benefits recently increased from 65 to 66 and will reach 67 for those born after 1959. Delayed retirement credits have been raised to better compensate retirees who take up benefits after the normal retirement age. Congress also repealed the earnings test, which reduced Social Security benefits for employed recipients older than the normal retirement age who earned more than a limited amount. ${ }^{1}$

Changes in employer-provided pension and retiree health benefits are also likely to encourage boomers to remain at work. Traditional DB pensions, which provide workers with lifetime retirement annuities usually based on years of service and earnings near the end of the career, tend to discourage work at older ages. They often provide substantial subsidies for early retirement and penalize workers who remain on the job past the plan's normal retirement age, because workers who delay retirement by a month forfeit a month of benefits. There is substantial evidence that workers in fact respond to the retirement incentives embedded in DB pension plans (see, for example, Stock and Wise 1990).

Over the past 30 years, however, employers have been shifting from traditional DB pensions to defined contribution (DC) plans, which do not encourage early retirement. Between

\footnotetext{
${ }^{1}$ The earnings test still applies to beneficiaries younger than the normal retirement age. Although beneficiaries whose payments are reduced by the earnings test are compensated with higher future benefits, some evidence suggests that the earnings test reduces work (Friedberg 2000).
} 
1975 and 2006 the share of private-sector workers participating in DB plans declined from 39 percent to 20 percent, while the share participating in DC plans increased from 15 percent to 43 percent (Bureau of Labor Statistics 2006; Pension and Welfare Benefits Administration 1998). Employers typically make specified contributions into individual DC accounts which workers access at retirement, generally as lump sum payments. Because contributions continue as long as plan participants remain employed and workers with a given account balance can receive the same lifetime benefit regardless of when they chose to begin collecting, DC plans do not generally penalize work at older ages. As a result, people in DC plans tend to work about two years longer than DB participants (Friedberg and Webb 2005), and the shift to DC plans should increase older Americans’ labor supply.

The erosion in employer-provided retiree health benefits is also likely to limit early retirement. Retiree health insurance, which pays health expenses for early retirees who have not reached the Medicare eligibility age of 65, discourages work by reducing retirement costs that arise from the loss of employer health benefits. Workers offered retiree health benefits by their employers retire earlier than workers who lose their health benefits (Blau and Gilleskie 2001; Johnson, Davidoff, and Perese 2003; Rogowski and Karoly 2000). However, rising health care costs and the introduction of an accounting rule in 1993 requiring employers to recognize on their balance sheets the full liability of future retiree health costs have led many employers to terminate their retiree health plans. In 2005, only 33 percent of employers with more than 200 employees offered retiree health benefits, down from 68 percent in 1988 (Kaiser Family Foundation and Health Research Educational Trust 2005).

Perhaps in response to these various trends, older adults are now working longer than they did about 20 years ago. Between 1985 and 2005, the share of men in the labor force 
increased from 46 percent to 53 percent at ages 62 to 64 and from 24 percent to 34 percent at ages 65 to 69 (Federal Interagency Forum on Aging Related Statistics 2006). Over the same period, female labor force participation rates rose from 29 percent to 40 percent at ages 62 to 64 and from 14 percent to 24 percent at ages 65 to 69 .

Several surveys also suggest that boomers intend to work into old age. For example, 68 percent of older workers in one recent poll said they intended to work in retirement (AARP 2003). Another AARP poll found that 38 percent of older workers want to phase gradually into retirement instead of leaving the labor force all together (AARP 2005). A recent MetLife survey found that boomers are increasingly concerned about their ability to afford retirement. Between 2001 and 2005, the share of boomers who reported that they would have enough money to retire before age 65 fell from 56 percent to 34 percent (MetLife Mature Market Institute 2005). The share never planning to retire increased from 7 percent to 17 percent.

A closer examination of retirement expectations for the leading edge of the baby boom cohort and the factors influencing those expectations may shed some light on how quickly the generation will exit the labor force. Retirement expectations appear to be reliable predictors of actual retirement behavior (Bernheim 1988; Dominitz 1996; Honig 1996).

\section{Methods}

This study compares the retirement expectations of workers ages 51 to 56 born between 1948 and 1953 (early boomers) to those of workers in the same age group born 12 years earlier, between 1936 and 1941 (the pre-war generation). We first compare retirement expectations and demographic and economic characteristics for each generation. Then we model retirement expectations for both generations to examine the key factors influencing anticipated labor force 
exits. Finally, we use the estimated regression coefficients and differences in characteristics to identify the forces that appear to drive generational differences in retirement expectations.

Our data come from the HRS, a national survey of Americans ages 51 and older conducted by the University of Michigan's Survey Research Center for the National Institute on Aging. The survey collects detailed information on retirement expectations, health status, employment, income, assets, employee benefits, and other topics. It oversamples African Americans and Hispanics but includes sample weights so that estimates represent the underlying national population. Our sample consists of 3,963 workers ages 51 to 56 in 1992 (from the prewar generation) and 2,145 workers in the same age group in 2004 (from the early boomers).

We use the self-reported probability of working full-time past typical retirement ages as our measure of retirement expectations. The survey asks respondents working for pay, "Thinking about work generally and not just your present job, what do you think are the chances that you will be working full-time after you reach age 62?” The survey asks the same question about work past age $65 .^{2}$

We use ordinary least squares (OLS) to model the subjective probabilities of working full-time past ages 62 and 65. Our analysis is grounded in a conceptual framework that assumes that rational workers weigh the costs and benefits of continued employment when making retirement decisions. We hypothesize that factors that increase work benefits will lead to later retirements, whereas factors that raise work costs will lead to earlier retirements. Model regressors that likely reduce the benefits of working at older ages or raise costs (and hence lower the chances of working past normal retirement ages) include DB pension coverage, retiree health benefit offers, poor health, household income net of own earnings, and household wealth.

\footnotetext{
${ }^{2}$ The survey also asked respondents when they expect to "retire," but we do not use this measure because the question changed over time and many respondents did not answer.
} 
Wealthy workers and those who derive income from sources other than employment face relatively low retirement costs, all else equal, because they can better maintain pre-retirement consumption levels than people with fewer financial resources. Factors in the model that increase work returns or reduce work costs include DC pension coverage, employer-sponsored health insurance coverage, earnings, self-employment, education, and the self-reported probability of surviving to age 75. The cost of working is generally lower for self-employed workers, who typically enjoy more workplace flexibility, than wage and salary workers. Well-educated workers typically face fewer physical job demands and more job flexibility than those with less education. High survival probabilities indicate good health and a relatively long period over which retirement wealth must be spread, increasing the cost of retiring early. The models also control for gender, marital status, race and ethnicity, and foreign birth.

Although most measures in our model are consistent over time, work limitations and retiree health insurance questions differ in 1992 and 2004. We measure poor health status by the presence of a health problem that limits work ability. In 2004, for the first time, the survey did not ask respondents who reported work limitations in the previous interview whether they continued to experience problems. We assume that work limitations reported in 2002 continued into 2004. Because work limitations sometimes disappear, our assumption may overstate the prevalence of 2004 work limitations (although only 25 percent of our 2004 sample of workers ages 51 to 56 were interviewed in 2002.) The retiree health insurance question also changed. In 1992, the HRS asked respondents whether their employers had "any health insurance plan available to retirees” and whether the plan could cover spouses. In 1996 and later years, it asked whether respondents could continue their employer insurance coverage up to age 65 if they left 
the employer at the time of the interview, and whether spouses could be covered. The wording change could affect estimated trends.

We express all financial amounts in constant 2004 dollars, adjusted by the change in the Consumer Price Index. Household wealth consists of financial assets (including DC and Individual Retirement Account balances), home equity, and other real assets. We account for differences in family size by dividing married respondents' household wealth and household income net of own earnings by 1.62, the midpoint of the range of household equivalence scales recommended by the National Academy of Science (Citro and Michael 1995).

The final stage of the analysis uses the regression coefficients and changes in characteristics between 1992 and 2004 to identify the major factors explaining the trend in retirement expectations. Following Oaxaca (1973), the difference between the two birth cohorts in the self-reported probability of working past the typical retirement age can be expressed as:

$$
\beta_{1992}\left(\bar{X}_{2004}-\bar{X}_{1992}\right)+\bar{X}_{2004}\left(\beta_{2004}-\beta_{1992}\right)
$$

or

$$
\beta_{2004}\left(\bar{X}_{2004}-\bar{X}_{1992}\right)+\bar{X}_{1992}\left(\beta_{2004}-\beta_{1992}\right)
$$

where $\bar{X}_{i}$ is the vector of mean explanatory variables for year $\mathrm{i}(\mathrm{i}=1992,2004)$ and $\beta_{\mathrm{i}}$ is the vector of regression coefficients for year i. The first term in equations 1 and 2 represents the portion of the difference in the self-reported probability that can be attributed to differences in observed characteristics between the cohorts, and the second term represents the unexplained portion of the difference. We focus on the first term to identify the major demographic and economic trends that explain changes in expectations. Because the portion of the generational gap accounted for by changes over time in particular characteristics may vary depending on whether pre-war generation coefficients or early boomer coefficients are used, we report results 
for both equations. We use weighted values for the demographic and economic characteristics and coefficients from weighted regressions so that our results generalize to the population of older American workers.

\section{Results}

Table 1 reports demographic and economic characteristics for workers ages 51 to 56 in 1992 and 2004. The comparisons revealed rapid changes in the older workforce over the 12-year period. Perhaps most striking was the sharp increase in educational attainment. For example, 37 percent of early boomers graduated from college, compared with only 22 percent of the pre-war generation. Whereas about 22 percent of the pre-war generation failed to complete high school, all but 10 percent of early boomers obtained their high school degrees.

Generational differences also reflected increases in female labor force participation and declines in marriage. Women made up about 50 percent of workers ages 51 to 56 in 2004, but only 46 percent in 1992. From 1992 to 2004, the share married declined from about 75 percent to 71 percent. Although the share of immigrants and Hispanics in the population increased during the 1990s (U.S. Census Bureau 2001a, 2001b), these trends were not apparent in the older workforce.

Traditional employer-sponsored pension plans and retiree health benefits declined substantially over the period. Between 1992 and 2004, the share of workers ages 51 to 56 with DB pension coverage on the current job fell from about 40 percent to 31 percent, while the share with DC plan coverage increased from about 34 percent to 46 percent. The portion of workers in their early and mid 50s with no pension coverage on the current job fell by about 3 percentage points over the period, to 39 percent. Although the prevalence of health insurance coverage on 
the job was similar for each generation, only about 39 percent of employed early boomers reported that their employers offered health benefits to retirees, down from about 56 percent for the pre-war generation.

The prevalence of work limitations among older workers did not fall over the period. In 2004, about 10 percent of workers ages 51 to 56 reported work limitations, up from 9 percent in 1992. Dropping from the 2004 sample respondents interviewed in 2002 — who we assumed had work limitations in 2004 if they reported problems in 2002 — reduced the share of workers with work limitations to about the same level as in 1992. The lack of health improvement over time did not appear to result from the movement of disabled workers into the labor force. Among all HRS respondents ages 51 to 56, regardless of employment status, 18 percent reported work limitations in 1992, compared with 19 percent in 2004 (among those not interviewed in 2002); the difference was not statistically significant. Consistent with the lack of improvement in work limitations, the self-reported probability of surviving to age 75 did not change significantly over time. The persistence of health problems may be related to rising diabetes and obesity rates among older Americans (Centers for Disease Control and Prevention 2005, 2006).

The early boomers reported more financial resources than the pre-war generation. Between 1992 and 2004, mean real earnings increased from about $\$ 43,000$ to $\$ 57,000$, mean real other household income increased from about $\$ 24,000$ to $\$ 32,000$, and mean real household wealth increased from $\$ 204,000$ to $\$ 284,000$. Much of these gains, however, were concentrated near the top of the distribution, as median resources increased more slowly. Median real earnings grew from $\$ 33,000$ to $\$ 41,000$, median real other income grew from $\$ 15,000$ to $\$ 18,000$, and median real wealth grew from $\$ 97,000$ to $\$ 119,000$. 
Table 2 shows mean self-reported expected probabilities of working full-time past age 62 — the first year people can start receiving Social Security retired worker benefits — for workers ages 51 to 56 in 1992 and 2004. Work expectations increased significantly over the period, with early boomers reporting a 51 percent chance of full-time work after age 62, compared with 47 percent for the pre-war generation. Except for Hispanics, immigrants, and those who did not complete high school, the probability of working past age 62 increased for all groups we examined, although the differences were not always statistically significant. The increase was especially striking for workers with DC plans, for whom work probabilities rose from 45 percent in 1992 to 52 percent in 2004.

Workers facing relatively high retirement costs or high returns to work generally reported higher work expectations. For example, mean work probabilities were especially high among college graduates, workers who expressed confidence in surviving to age 75, workers without access to retiree health benefits, and the self-employed. The mean probability of remaining at work full-time beyond age 62 reached 59 percent in 2004 for self-employed workers ages 51 to 56. Conversely, workers who faced difficult employment conditions, who did not gain much by remaining at work, or who could retire without lowering their living standards were less likely to expect to remain employed at older ages. These workers included those with DB pension coverage, those with work limitations, and those in the top third of the household wealth distribution. Additionally, men, single adults, and whites reported higher work expectations than women, married adults, and African Americans or Hispanics.

Table 3 compares mean expected probabilities of working full-time past age 65 for workers ages 51 to 56 in 1992 and 2004. The mean probability rose about 6 percentage points over the period, from about 27 percent to about 33 percent, nearly double the increase in the 
mean probability of working full-time past age 62. In relative terms, work expectations after age 65 were about 23 percent higher for the early boomers than the pre-war generation. Except for foreign born adults, work expectations increased for all of the groups we examined, and the increases were statistically significant for all groups except Hispanics, those without pension coverage or employer retiree health benefits, and the self-employed.

Table 4 shows coefficients and standard errors from weighted OLS regressions of the self-reported probability of working full-time past age 62 in 1992 and 2004. The findings generally confirmed our hypothesis that older workers were more likely to remain employed as both the benefits of working and the costs of retiring increased. For example, workers with DB pension coverage, who typically lose pension wealth if they delay retirement, were about 8 percentage points less likely to expect to remain employed after age 62 than other workers, holding other factors constant. Work expectations in 2004 were about 11 percentage points higher for the self-employed, who generally enjoy flexible workplaces, than wage and salary workers. Wealth, income, and the availability of employer-sponsored retiree health benefits, all of which make retirement more affordable, lowered work expectations. Earnings and the availability of employer health benefits while working, which raise the gains from work, increased employment expectations at older ages in 2004. People with work limitations were significantly less likely to expect to remain employed than people in better health, whereas workers who expected to survive past age 75 were more likely to remain employed than those with lower self-assessed survival probabilities. Women, married adults, and African Americans were significantly less likely to expect to work past age 62 than men, single adults, and whites.

Table 5 reports results from weighted OLS regressions of the self-reported probability of working past age 65 in 1992 and 2004. The estimates were quite similar to those reported in table 
4 for the probability of working past age 62. Self-employment exerted an even larger impact on the expectation of working past age 65 than age 62, increasing the probability by about 13 percentage points. However, employer health insurance coverage for workers did not significantly increase work expectations after age 65, probably because Medicare benefits begin at 65. Earnings were also insignificant predictors of work expectations past age 65.

Table 6 identifies the demographic and economic trends that most contribute to the increase in work expectations across the two cohorts. The table shows the portion of the increase in average work probabilities past ages 62 and 65 attributable to changes in each characteristic, according to the Oaxaca (1973) decomposition. The contribution of each trend was calculated by multiplying the regression coefficients reported in tables 4 and 5 by the change in characteristics reported in table 1. Because the share attributed to each factor depended on whether we used coefficients from the 1992 regressions of those from 2004, we report separate results based on both sets of coefficients.

Lower rates of retiree health insurance offers from employers, higher levels of educational attainment, and lower rates of defined benefit pension coverage accounted for most of the increase between 1992 and 2004 in expected work probabilities after ages 62 and 65. The decline in retiree health benefits accounted for between 30 and 47 percent of the rise in work expectations after age 62 and between 9 and 20 percent of the rise in work expectations after age 65. Between 28 and 33 percent of the increase in the expected probability of working past age 62 could be explained by the increase in college graduation rates among boomers and the decline in high school dropout rates, as could between 13 and 22 percent of the increase in the expected probability of working past 65 . The shift away from DB pension plans explained about one-fifth of the increase in expected work probabilities after age 62 and about one-eighth of the increase 
after age 65. These three factors combined explained between 81 and 100 percent of the increase in expected work probabilities after age 62 and between 35 and 55 percent of the increase after age 65. Other factors had much smaller effects. For example, the decline in marriage rates explained no more than 8 percent of the rise in work expectations. The trend toward higher income and wealth and the movement of women into the labor force reduced expected employment at older ages below the levels that would have prevailed if income, wealth, and female labor force participation had remained at their 1992 levels.

\section{Discussion}

Our results show that early boomers expect to work longer than people born 12 years earlier. The mean probability of working full-time beyond age 65 reached 33 percent for workers ages 51 to 56 in 2004, up from 27 percent for workers in the same age group in 1992. But will

early boomers in fact delay retirement, and will the trend continue for later boomers? The answer likely depends, in part, on whether the recent trend in work characteristics and demographics continues.

The erosion of employer retiree health benefits, which explains as much as half of the increase in work expectations, will likely persist. Although the decline in retiree health insurance offers occurred mostly in the late 1980s and early 1990s as new accounting regulations took hold, rising health care costs will likely lead to further coverage declines (McCormack et. al 2002; GAO 2001). Between 2003 and 2004, for example, the cost to large employers of providing retiree health insurance increased by 13 percent (McArdle et. al, 2004). The aging of the workforce will further pressure employers who provide retiree health insurance. Unlike rules governing DB pension plans, federal law does not force employers to set aside funds for future 
retiree health benefits or prevent them from cutting promised benefits. Even if coverage rates do not decline further, employers are likely to shift costs to retirees. In 2005, 85 percent of large employers offering retiree health benefits said they were likely to increase retiree contributions in the coming year, and 18 percent said were likely to make retirees pay the entire premium (McArdle et. al, 2004).

The trend away from DB pensions, which explains as much as 23 percent of the increase in work expectations, shows no signs of abating. For example, Watson Wyatt (2006) found that many employers terminated or froze their DB pension plans between 2004 and 2006, and 15 percent of employers surveyed by Hewitt Associates in 2006 reported that they were likely to close their plans to new employees in the coming year (Taub 2006).

Additionally, a recent court decision and federal legislation will likely encourage employers to convert their traditional DB pension plans to cash balance plans, which do not generally penalize work at older ages. Employers offering cash balance plans, which combine elements of DC and traditional DB plans, regularly set aside a given percentage of salary for each employee and credit interest on these contributions. Like DC plans, cash balance plans create strong work incentives because additional plan contributions increase workers' account balances. Although many employers switched to cash balance plans during the 1990s, recent legal challenges put future conversions on hold. In August 2006, however, the Seventh Circuit Court of Appeals ruled that cash balance plans do not violate age discrimination rules, and President Bush signed the Pension Protection Act of 2006, declaring that cash balance plans are not age discriminatory.

Demographic trends that encourage work at older ages are also likely to continue. The share of young adults with college degrees reached an all time high in 2003, but declined in the 
late 1970s and early 1980s before increasing in the 1990s (U.S. Census Bureau 2004). As a result, the share of workers approaching retirement with a college education will likely stagnate over the coming decade, but then rise in later years. Declining marriage rates will likely raise for the foreseeable future the share of workers approaching retirement who are single (Smith and Toder 2005). The movement of women into the labor force, which reduced work expectations between 1992 and 2004, is likely to slow in the future. Between 1984 and 2004, labor force participation rates for women ages 45 to 54 increased from 62 percent to 77 percent between 1984 and 2004, but will increase to only 78 percent by 2014, according to Bureau of Labor Statistics projections (Toosi 2005). However, rising real incomes and wealth will somewhat reduce employment at older ages.

Taken together, these trends and our HRS analysis suggest that the boomers will remain at work longer than the previous generation. The recent uptick in average retirement ages appears to be the leading edge of a new long-term trend. Lengthier careers will likely promote economic growth, increase government revenue, and improve individual financial security at older ages.

\section{References}

AARP. 2003. Staying Ahead of the Curve 2003: The AARP Working in Retirement Study. Washington, DC: AARP.

AARP. 2005. Attitudes of Individuals 50 and Older Toward Phased Retirement. Washington, DC: AARP.

Aspen Institute. 2003. Grow Faster Together. Or Grow Slowly Apart: How Will America Work in the 21st Century?. Washington, DC: The Aspen Institute.

Bernheim, B. Douglas. 1988. "Social Security benefits: An empirical study of expectations and realizations." In Issues in Contemporary Retirement, edited by Edward P. Lazear and Rita Ricardo-Campbell (312-345). Palo Alto: Hoover Institution. 
Blau, David M. and Donna B. Gilleskie. 2001. "Retiree Health Insurance and The Labor Force Behavior of Older Men In The 1990s.” The Review of Economics and Statistics, 83(1): 64-80.

Bound, John, Michael Schoenbaum, Todd R. Stinebricker, and Timothy Waidmann. 1998. “The Dynamic Effects of Health on the Labor Force Transitions of Older Workers.” NBER Working Paper \#6777. Cambridge, MA: National Bureau of Economic Research.

Board of Trustees of the Federal Hospital Insurance and Federal Supplementary Medical Insurance Trust Funds. 2006. Annual Report. Washington, DC: U.S. Government Printing Office.

Board of Trustees of the Federal Old-Age and Survivors Insurance and Disability Insurance Trust Funds. 2006. Annual Report. Washington, DC: U.S. Government Printing Office.

Bureau of Labor Statistics. 2006. National Compensation Survey: Employee Benefits in Private Industry in the United States, March 2006. Washington, DC: U.S. Department of Labor.

Burtless, Gary and Joseph F. Quinn. 2000. "Retirement Trends and Policies to Encourage Work Among Older Americans.” Chestnut Hill, MA: Center for Retirement Research at Boston College.

Butrica, Barbara A., Richard W. Johnson, Karen E. Smith, and Eugene Steuerle. 2005. "Does Work Pay at Older Ages?” Washington, DC: The Urban Institute.

Cappelli, Peter. 2005. "Will There Really Be a Labor Shortage?" Human Resource Management 44(2): 143-149.

Centers for Disease Control and Prevention. 2005. "Prevalence of Diagnosed Diabetes by Age, United States.” http://www.cdc.gov/diabetes/statistics/prev/national/figbyage.htm.

. 2006. “State-Specific Prevalence of Obesity Among Adults --- United States, 2005.” Morbidity and Mortality Weekly Report 55(36): 985-988. http://www.cdc.gov/mmwr/preview/mmwrhtml/mm5536a1.htm\#tab.

Citro, Constance F., and Robert T. Michael, editors. 1995. Measuring Poverty: A New Approach. Washington, DC: National Academy Press.

Kaiser Family Foundation and Health Research Educational Trust. 2005. Employer Health Benefits: 2005 Annual Survey. Menlo Park, California and Chicago, Illinois: Kaiser Family Foundation and Health Research Educational Trust.

Costa, Dora L. 1998. The Evolution of Retirement: An American Economic History, 1880-1990. Chicago, Illinois: University of Chicago Press. 
Dominitz, J., 1996. “A Comparison of Subjective Expectations Elicitation Methods in the Health and Retirement Study, the Panel Study of Income Dynamics, and the Survey of Economic Expectations.” HRS/AHEAD Working Paper \# 96-043.

Dwyer, D.S. and O.S. Mitchell, 1999. "Health Shocks as Determinants of Retirement: Are SelfRated Measures Endogenous?” Journal of Health Economics, 18: 173-193.

Federal Interagency Forum on Aging Related Statistics. 2006. Older Americans Update 2006: Key Indicators of Well-Being. Washington, DC: U.S. Government Printing Office.

Friedberg, Leora. 2000. "The Labor Supply Effects of the Social Security Earnings Test.” Review of Economics and Statistics, 82(1):48-63.

Friedberg, Leora and Anthony Webb. 2005. "Retirement and the Evolution of Pension Structure.” The Journal of Human Resources, 40(2): 281-308.

Government Accountability Office (GAO). 2001. Retiree Health Benefits: Employer-Sponsored Benefits May Be Vulnerable to Further Erosion. GAO-01-374. Washington, DC: Government Accountability Office.

Honig, Marjorie. 1996. "Retirement Expectations: Differences by Race, Ethnicity, and Gender.” Gerontologist 36 (3): 373-82.

Johnson, Richard W., Amy J. Davidoff, and Kevin Perese. 2003. "Health Insurance Costs and Early Retirement Decisions.” Industrial and Labor Relations Review 56(4): 716-729.

McArdle, Frank, Amy Atchison, Dale Yamamoto, Michelle Kitchman, and Tricia Neuman. 2004. Current Trends and Future Outlook for Retiree Health Benefits: Findings from the Kaiser/Hewett 2004 Survey on Retiree Health Benefits. Lincolnshire, Illinois and Menlo Park, California: Hewitt Associates and The Kaiser Family Foundation.

McCormack, Lauren A., Jon R. Gabel, Nancy D. Berkman, Heidi Whitmore, Kay Hutchinson, Wayne L. Anderson, Jeremy Pickreign, and Nathan West. 2002. "Retiree Health Insurance: Recent Trends and Tomorrow's Prospects.” Health Care Financing Review 23(3): 17-34.

McGarry, Kathleen. 2004. "Health and Retirement: Do Changes in Health Affect Retirement Expectations?” The Journal of Human Resources 39(3): 624-648.

MetLife Mature Market Institute. 2005. The MetLife Survey of American Attitudes Toward Retirement: What's Changed. Westport, CT: MetLife Mature Market Institute.

National Association of State Retirement Administrators. 2006. Public Fund Survey. http://www.publicfundsurvey.org/publicfundsurvey/index.htm. 
National Center for Health Statistics. 2006. "Trends in Health and Aging." http://209.217.72.34/aging/TableViewer/tableView.aspx?ReportId=313

Nyce, Steven A. and Sylvester J. Shieber. 2001. "The Decade of the Employee: The Workforce Environment in the Coming Decade.” Benefits Quarterly, fourth quarter.

Oaxaca, Ronald. 1973. "Male-Female Wage Differentials in Urban Labor Markets.” International Economic Review 14(3): 693-709.

Pension Benefit Guaranty Corporation. 2005. Annual Report. Washington, DC: U.S. Government Printing Office.

Pension and Welfare Benefits Administration. 1998. Private Pension Plan Bulletin: Abstract of 1994 Form 5500 Annual Reports. Washington, DC: U.S. Department of Labor.

Rogowski, Jeannette and Lynn Karoly. "Health Insurance and Retirement Behavior: Evidence from the Health and Retirement Survey.” Journal of Health Economics, 19(4): 529-539.

Smith, Karen E., and Eric J. Toder. 2005. "Changing Demographics of the Retired Population.” Older Americans’ Economic Security No. 5. Washington, DC: The Urban Institute.

Steuerle, C. Eugene, Christopher Spiro, and Richard W. Johnson. 1999. "Can Americans Work Longer?” Straight Talk on Social Security and Retirement Policy No. 5. Washington, D.C.: The Urban Institute.

Stock, James H. and David A. Wise. 1990. "The Pension Inducement to Retire: An Option Value Analysis.” In Issues in the Economics of Aging, edited by David A. Wise (205-229). Chicago, Illinois: University of Chicago Press.

Taub, Stephen. "Pension Plans Disappearing." CFO.com. http://www.cfo.com/article.cfm/7108045/c_7146188

Toosi, Mitra. 2002. “A Century of Change: The U.S. Labor Force, 1950-2050.” Monthly Labor Review 125(5): 15-28. . 2005. "Labor force projections to 2014: retiring boomers." Monthly Labor Review 128(11): 25-44.

U.S. Census Bureau. 2001a. "Population by Race and Hispanic or Latino Origin for the United States: 1990 and 2000.” Census 2000 PHC-T-1. http://www.census.gov/population/cen2000/phc-t1/tab04.pdf.

. 2001b. The Population Profile of the United States: 2000, internet release, http://www.census.gov/population/pop-profile/2000/profile2000.pdf. 
. 2004. Educational Attainment in the United States: 2003. Current Population Reports P20-550. Washington, DC: U.S. Census Bureau.

. 2005. Educational Attainment from Current Population Survey. http://www.census.gov/population/socdemo/education/tabA-1.xls.

Watson Wyatt. 2006. "Watson Wyatt Urges Congress to Seize Opportunity to Shore Up Nation's Pension System.” Press release. http://www.watsonwyatt.com/news/press.asp?ID=16201. 
Table 1. Demographic and Economic Characteristics of Workers Ages 51 to 56, 1992 and 2004

Share With Characteristic (\%)

Female

Married

\section{Education}

Did not complete high school

High school graduate

College graduate

\section{Race}

White, other

African American

Hispanic

Foreign Born

Pension Coverage (current job)

DB

DC

None

Employer Health Insurance Coverage

Employer Retiree Health Insurance Offer

Any Health-Related Work Limitation

Self Employed

\section{Mean Value}

Self-Reported Probability of Surviving to Age 75

66.9

65.5

Earnings (\$2004)

Other Household Income (\$2004)

Household Wealth (\$2004)

$\mathbf{N}$

Source: Authors' estimates from the Health and Retirement Study (HRS).
45.5

$50.1^{\star \star \star}$

74.9

$70.8^{\star \star \star}$

22.1

55.6

22.4

$10.1^{\star \star \star}$

52.9

$37.0^{\star * *}$

85.0

9.2

83.0

5.9

9.1

9.4

9.8

39.9

33.5

$30.5^{\star \star \star}$

$45.8^{\star \star \star}$

$39.2^{*}$

63.0

64.8

55.7

$38.7^{\text {*** }}$

8.7

$10.4^{*}$

18.1

16.3

Note. Household wealth consists of financial assets (including DC and Individual Retirement Account balances), home equity, and other real assets. Other household income includes spouse earnings, capital income, pensions, and government transfers. To account for differences in family size, married respondents' household wealth and other income are divided by 1.62. Estimates are weighted to account for the HRS sampling probabilities.

Asterisks indicate significant differences between 1992 and 2004:

* $p<.10 ; \quad$ ** $p<.05 ; \quad$ *** $p<.01$ 
Table 2. Mean Expected Probability of Working Full Time Past Age 62, Among Workers Ages 51 to $56(\%)$

\begin{tabular}{|c|c|c|c|c|}
\hline & \multicolumn{2}{|c|}{1992} & \multicolumn{2}{|c|}{2004} \\
\hline & $\mathbf{N}$ & Mean & $\mathbf{N}$ & Mean \\
\hline All & 3963 & 47.2 & 2155 & $50.7^{\wedge}$ \\
\hline \multicolumn{5}{|l|}{ Gender } \\
\hline Male & 2123 & 51.1 & 996 & $55.6^{\wedge}$ \\
\hline Female & 1840 & $42.5 * \star *$ & 1159 & $45.8 * \star \star \wedge$ \\
\hline \multicolumn{5}{|l|}{ Marital Status } \\
\hline Married & 2985 & 45.7 & 1507 & $48.7 \wedge$ \\
\hline Single & 978 & $51.4 * \star *$ & 646 & $55.4 * \star \star$ \\
\hline \multicolumn{5}{|l|}{ Education } \\
\hline Did not complete high school & 999 & 44.0 & 270 & 43.8 \\
\hline High school graduate & 2159 & 46.8 * & 1,143 & $50.3^{* *}, \wedge$ \\
\hline College graduate & 805 & 51.1 *** & 742 & $53.2 * * \star$ \\
\hline \multicolumn{5}{|l|}{ Race } \\
\hline White, other & 2999 & 47.7 & 1,607 & $51.7 \wedge$ \\
\hline African American & 633 & 40.8 *** & 291 & $45.0 * \star \star$ \\
\hline Hispanic & 331 & 49.5 & 257 & $47.0 * \star$ \\
\hline \multicolumn{5}{|l|}{ Nativity } \\
\hline Native Born & 3558 & 46.5 & 1,886 & $51.2^{\wedge}$ \\
\hline Foreign Born & 405 & 53.1 ** & 269 & 46.3 ** \\
\hline \multicolumn{5}{|l|}{ Pension Coverage (current job) } \\
\hline No Coverage & 1704 & 51.1 & 872 & 51.7 \\
\hline DB & 1542 & $41.8 * * *$ & 639 & 45.5 ** \\
\hline DC & 1257 & $44.5 * * *$ & 927 & $52.4^{\wedge}$ \\
\hline \multicolumn{5}{|c|}{ Employer Health Insurance Coverage? } \\
\hline Yes & 2443 & 47.1 & 1,371 & $51.4^{\wedge}$ \\
\hline No & 1490 & 47.6 & 783 & 49.3 \\
\hline \multicolumn{5}{|c|}{ Employer Retiree Health Insurance Offer? } \\
\hline Yes & 2136 & 41.6 & 801 & $45.8^{\wedge}$ \\
\hline No & 1783 & 53.8 *** & 1,330 & $53.9 * \star \star$ \\
\hline \multicolumn{5}{|l|}{ Health Limits Ability to Work? } \\
\hline Yes & 341 & 40.5 & 224 & 44.7 \\
\hline No & 3621 & $47.8 * * *$ & 1,927 & $51.4^{* *}, \wedge$ \\
\hline \multicolumn{5}{|l|}{ Self Employed? } \\
\hline Yes & 690 & 57.4 & 341 & 59.2 \\
\hline No & 3273 & $44.9 * \star *$ & 1813 & $49.1^{* \star \star}, \wedge$ \\
\hline \multicolumn{5}{|l|}{ Earnings } \\
\hline Bottom third & 1331 & 45.2 & 719 & 46.9 \\
\hline Middle third & 1356 & 48.8 & 723 & $53.6 * \star \star \wedge$ \\
\hline Top third & 1276 & 47.4 & 713 & $51.3 * *$ \\
\hline \multicolumn{5}{|l|}{ Wealth } \\
\hline Bottom third & 1323 & 52.6 & 718 & 53.7 \\
\hline Middle third & 1319 & $46.0 * \star *$ & 719 & $52.0^{\wedge}$ \\
\hline Top third & 1321 & 44.0 *** & 718 & $47.2 * \star \star, \wedge$ \\
\hline \multicolumn{5}{|l|}{ Probability of Surviving Past 75} \\
\hline $1-50$ & 1218 & 43.8 & 717 & $48.9 \wedge$ \\
\hline $51-80$ & 1158 & 47.6 ** & 723 & $53.3 * *, \wedge$ \\
\hline $81-100$ & 1123 & $50.9 * * *$ & 564 & $52.7 *$ \\
\hline 0 & 199 & $32.1 * * *$ & 96 & $34.8 * \star *$ \\
\hline
\end{tabular}

Source: Authors' estimates from the Health and Retirement Study.

Note. Household wealth consists of financial assets (including DC and Individual Retirement Account balances), home equity, and other real assets. Other household income includes spouse earnings, capital income, pensions, and government transfers. To account for differences in family size, married respondents' household wealth and other income are divided by 1.62. Estimates are weighted to account for the HRS sampling probabilities. Asterisks indicate significant differences between the given value and the value in the first row for the group $\left({ }^{*} \mathrm{p}<.10 ; \quad * \star p<.05 ; \quad * \star *<.01\right)$. ^ indicates significant difference $(p<.05)$ in the mean value for the given group between 1992 and 2004. 
Table 3. Mean Expected Probability of Working Full Time Past Age 65, Among Workers Ages 51 to $56(\%)$

\begin{tabular}{|c|c|c|c|c|}
\hline & \multicolumn{2}{|c|}{1992} & \multicolumn{2}{|c|}{2004} \\
\hline & $\mathbf{N}$ & Mean & $\mathbf{N}$ & Mean \\
\hline All & 3963 & 26.6 & 2155 & $32.8 \wedge$ \\
\hline \multicolumn{5}{|l|}{ Gender } \\
\hline Male & 2123 & 29.7 & 996 & $36.5 \wedge$ \\
\hline Female & 1840 & $22.9 * * *$ & 1159 & $29.1 * * *, \wedge$ \\
\hline \multicolumn{5}{|l|}{ Marital Status } \\
\hline Married & 2985 & 25.0 & 1507 & $31.0^{\wedge}$ \\
\hline Single & 978 & $31.2 * * *$ & 646 & $37.0 * * *, \wedge$ \\
\hline \multicolumn{5}{|l|}{ Education } \\
\hline Did not complete high school & 999 & 23.3 & 270 & $29.4 \wedge$ \\
\hline High school graduate & 2159 & $26.1 * *$ & 1,143 & $32.2 \wedge$ \\
\hline College graduate & 805 & $30.8 * * *$ & 742 & $34.5 * *, \wedge$ \\
\hline \multicolumn{5}{|l|}{ Race } \\
\hline White, other & 2999 & 26.7 & 1,607 & $33.3 \wedge$ \\
\hline African American & 633 & $21.8 * \star *$ & 291 & $27.9 * *, \wedge$ \\
\hline Hispanic & 331 & $31.6 * * *$ & 257 & 32.5 \\
\hline \multicolumn{5}{|l|}{ Nativity } \\
\hline Native born & 3558 & 26.1 & 1,886 & $33.1 \wedge$ \\
\hline Foreign born & 405 & $31.4 * *$ & 269 & 29.6 * \\
\hline \multicolumn{5}{|l|}{ Pension Coverage (current job) } \\
\hline No Coverage & 1704 & 34.4 & 872 & 37.0 \\
\hline DB & 1542 & $19.0 * \star *$ & 639 & $26.1 * \star \star, \wedge$ \\
\hline $\mathrm{DC}$ & 1257 & $21.7 * * *$ & 927 & $31.7^{* * *}, \wedge$ \\
\hline \multicolumn{5}{|c|}{ Employer Health Insurance Coverage? } \\
\hline Yes & 2443 & 24.1 & 1,371 & $31.7 \wedge$ \\
\hline No & 1490 & $31.1 * \star \star$ & 783 & $34.7 * *, \wedge$ \\
\hline \multicolumn{5}{|c|}{ Employer Retiree Health Insurance Offer? } \\
\hline Yes & 2136 & 20.8 & 801 & $28.9 \wedge$ \\
\hline No & 1783 & $33.6 * * *$ & 1,330 & $35.2 * \star *$ \\
\hline \multicolumn{5}{|c|}{ Any Health-Related Work Limitations? } \\
\hline Yes & 341 & 21.9 & 224 & $29.7^{\wedge}$ \\
\hline No & 3621 & $27.0 * * *$ & 1,927 & $33.1 \wedge$ \\
\hline \multicolumn{5}{|l|}{ Self Employed? } \\
\hline Yes & 690 & 42.3 & 341 & 45.0 \\
\hline No & 3273 & $23.1 * \star *$ & 1813 & $30.3 * * *, \wedge$ \\
\hline \multicolumn{5}{|l|}{ Earnings } \\
\hline Bottom third & 1331 & 27.8 & 719 & $32.3 \wedge$ \\
\hline Middle third & 1356 & 25.4 & 723 & $34.2 \wedge$ \\
\hline Top third & 1276 & 26.5 & 713 & $31.8^{\wedge}$ \\
\hline \multicolumn{5}{|l|}{ Household Wealth } \\
\hline Bottom third & 1323 & 31.3 & 718 & $36.4^{\wedge}$ \\
\hline Middle third & 1319 & $23.8 * \star \star$ & 719 & $32.8 *, \wedge$ \\
\hline Top third & 1321 & $25.4 * \star \star$ & 718 & $29.9 * \star \star, \wedge$ \\
\hline \multicolumn{5}{|l|}{ Probability of Surviving Past 75} \\
\hline $1-50$ & 1218 & 23.6 & 717 & $30.8^{\wedge}$ \\
\hline $51-80$ & 1158 & $26.7 * *$ & 723 & $34.9 * *, \wedge$ \\
\hline $81-100$ & 1123 & $29.8 * * *$ & 564 & $34.8 * *, \wedge$ \\
\hline 0 & 199 & $15.4 * \star \star$ & 96 & $20.5 * * \star$ \\
\hline
\end{tabular}

Source: Authors' estimates from the Health and Retirement Study.

Note. Household wealth consists of financial assets (including DC and Individual Retirement Account balances), home equity, and other real assets. Other household income includes spouse earnings, capital income, pensions, and government transfers. To account for differences in family size, married respondents' household wealth and other income are divided by 1.62. Estimates are weighted to account for the HRS sampling probabilities. Asterisks indicate significant differences between the given value and the value in the first row for the group $\left({ }^{*} p<.10 ; \quad{ }^{*} p<.05 ;{ }^{* \star *} p<.01\right){ }^{\wedge}$ indicates significant difference $(p<.05)$ in the mean value for the given group between 1992 and 2004. 
Table 4. Coefficients (with standard errors) from Regressions of Expected Probability of Working Past 62

\begin{tabular}{|c|c|c|c|c|}
\hline & 1992 & & 2004 & \\
\hline Male & $\begin{array}{r}8.586 \\
(1.386)\end{array}$ & *** & $\begin{array}{r}9.046 \\
(1.515)\end{array}$ & $* \star \star$ \\
\hline Married & $\begin{array}{r}-5.408 \\
(1.710)\end{array}$ & *** & $\begin{array}{l}-6.851 \\
(2.211)\end{array}$ & *** \\
\hline \multicolumn{5}{|l|}{ Education } \\
\hline Did not complete high school & $\begin{array}{r}-4.952 \\
(1.351)\end{array}$ & *** & $\begin{array}{l}-5.198 \\
(2.677)\end{array}$ & * \\
\hline [Reference: High school graduate] & $\ldots$ & & $\ldots$ & \\
\hline College graduate & $\begin{array}{r}4.074 \\
(1.445)\end{array}$ & *** & $\begin{array}{r}2.465 \\
(2.009)\end{array}$ & \\
\hline \multicolumn{5}{|l|}{$\begin{array}{l}\text { Race and Ethnicity } \\
\text { [Reference: White or other] }\end{array}$} \\
\hline African American & $\begin{array}{l}-7.111 \\
(2.008)\end{array}$ & *** & $\begin{array}{l}-7.536 \\
(2.352)\end{array}$ & $* \star \star$ \\
\hline Hispanic & $\begin{array}{r}-1.034 \\
(2.154)\end{array}$ & & $\begin{array}{r}-0.278 \\
(3.223)\end{array}$ & \\
\hline Foreign Born & $\begin{array}{r}4.221 \\
(2.732)\end{array}$ & & $\begin{array}{r}-5.010 \\
(2.795)\end{array}$ & * \\
\hline \multicolumn{5}{|l|}{ Pension Coverage } \\
\hline DB & $\begin{array}{l}-7.500 \\
(1.461)\end{array}$ & *** & $\begin{array}{l}-8.477 \\
(2.275)\end{array}$ & *** \\
\hline DC & $\begin{array}{r}-3.064 \\
(1.675)\end{array}$ & * & $\begin{array}{r}2.654 \\
(1.730)\end{array}$ & \\
\hline Employer Health Insurance Coverage & $\begin{array}{r}6.559 \\
(1.516)\end{array}$ & *** & $\begin{array}{r}3.839 \\
(1.629)\end{array}$ & *** \\
\hline Employer Retiree Health Insurance Offer & $\begin{array}{r}-9.779 \\
(1.360)\end{array}$ & $* * *$ & $\begin{array}{r}-6.400 \\
(1.479)\end{array}$ & $* \star \star$ \\
\hline Health-Related Work Limitation & $\begin{array}{c}-7.403 \\
(2.161)\end{array}$ & *** & $\begin{array}{l}-6.997 \\
(2.850)\end{array}$ & $* \star \star$ \\
\hline Self Employed & $\begin{array}{r}8.998 \\
(2.026)\end{array}$ & $* * *$ & $\begin{array}{l}10.705 \\
(2.899)\end{array}$ & *** \\
\hline Self-Reported Probability of Living to 75 & $\begin{array}{r}0.143 \\
(0.031)\end{array}$ & $* * \star$ & $\begin{array}{r}0.139 \\
(0.031)\end{array}$ & $* * *$ \\
\hline Earnings (in 100,000 of 2004 dollars) & $\begin{array}{c}-0.037 \\
(1.600)\end{array}$ & & $\begin{array}{r}2.410 \\
(0.962)\end{array}$ & $* \star *$ \\
\hline Income (in 100,000 of 2004 dollars) & $\begin{array}{r}-4.570 \\
(2.380)\end{array}$ & * & $\begin{array}{l}-3.930 \\
(2.050)\end{array}$ & * \\
\hline Wealth (in 100,000 of 2004 dollars) & $\begin{array}{c}-0.364 \\
(0.199)\end{array}$ & * & $\begin{array}{l}-0.548 \\
(0.212)\end{array}$ & $* * *$ \\
\hline Constant & 43.085 & & 44.641 & \\
\hline Mean Expected Probability of Working Past 62 & 47.15 & & 50.7 & \\
\hline $\begin{array}{l}\mathbf{N} \\
\mathbf{R}^{2}\end{array}$ & 3,963 & & 2,155 & \\
\hline $\mathbf{R}^{2}$ & 0.089 & & 0.099 & \\
\hline
\end{tabular}

Source: Authors' estimates, based on data from the HRS.

Note: Weighted OLS regressions on a sample of workers ages 51 to 56 . See table 2 for additional details.

${ }^{*} \mathrm{p}<.10 ; \quad{ }^{* \star} \mathrm{p}<.05 ; \quad * * * \mathrm{p}<.01$ 
Table 5. Coefficients (with standard errors) from Regressions of Expected Probability of Working Past Age 65

\begin{tabular}{|c|c|c|c|}
\hline \multirow[b]{2}{*}{ Male } & 1992 & \multicolumn{2}{|l|}{2004} \\
\hline & $\begin{array}{l}7.290 \\
(1.097)\end{array}$ & $\begin{array}{r}7.269 \\
(1.496)\end{array}$ & *** \\
\hline Married & $\begin{array}{l}-7.0711^{* \star \star} \\
(1.451)\end{array}$ & $\begin{array}{l}-6.116 \\
(2.083)\end{array}$ & 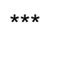 \\
\hline Education & & & \\
\hline $\begin{array}{l}\text { Did not complete high school } \\
\text { [Reference: High school graduate] }\end{array}$ & $\begin{array}{c}-5.550 * \star * \\
(1.346) \\
\ldots\end{array}$ & $\begin{array}{r}-3.051 \\
(2.238) \\
\ldots\end{array}$ & \\
\hline College graduate & $\begin{aligned} 4.776 & \\
(1.319) & \end{aligned}$ & $\begin{array}{r}3.000 \\
(1.872)\end{array}$ & \\
\hline $\begin{array}{l}\text { Race and Ethnicity } \\
\text { [Reference: White or other] }\end{array}$ & & $\ldots$ & \\
\hline African American & $\begin{array}{l}-4.619 * \star * \\
(1.305)\end{array}$ & $\begin{array}{r}-6.590 \\
(2.320)\end{array}$ & $* * *$ \\
\hline Hispanic & $\begin{array}{rl}3.823 & * \\
(2.001)\end{array}$ & $\begin{array}{r}2.143 \\
(2.993)\end{array}$ & \\
\hline Foreign Born & $\begin{array}{r}1.425 \\
(2.480)\end{array}$ & $\begin{array}{r}-5.666 \\
(2.627)\end{array}$ & ** \\
\hline Pension Coverage & & & \\
\hline DB & $\begin{array}{l}-8.696 * \star \star \\
(1.399)\end{array}$ & $\begin{array}{r}-8.652 \\
(1.704)\end{array}$ & *** \\
\hline DC & $\begin{array}{l}-4.715 * * * \\
(1.308)\end{array}$ & $\begin{array}{r}-0.475 \\
(1.867)\end{array}$ & \\
\hline Employer Health Insurance Coverage & $\begin{array}{r}1.451 \\
(1.291)\end{array}$ & $\begin{array}{r}0.504 \\
(1.422)\end{array}$ & \\
\hline Employer Retiree Health Insurance Offer & $\begin{array}{l}-7.265 * \star * \\
(1.180)\end{array}$ & $\begin{array}{r}-3.189 \\
(1.498)\end{array}$ & ** \\
\hline Health-Related Work Limitation & $\begin{array}{l}-5.928 * * * \\
(1.596)\end{array}$ & $\begin{array}{l}-4.708 \\
(2.417)\end{array}$ & * \\
\hline Self Employed & $\begin{array}{l}12.593 * \star * \\
(1.997)\end{array}$ & $\begin{array}{l}13.097 \\
(2.583)\end{array}$ & *** \\
\hline Self-Reported Probability of Surviving to 75 & $\begin{array}{l}0.118 \text { *** } \\
(0.018)\end{array}$ & $\begin{array}{r}0.136 \\
(0.030)\end{array}$ & *** \\
\hline Earnings (in 100,000 of 2004 dollars) & $\begin{array}{r}1.310 \\
(1.450)\end{array}$ & $\begin{array}{r}1.040 \\
(0.837)\end{array}$ & \\
\hline Income (in 100,000 of 2004 dollars) & $\begin{array}{r}-2.030 \\
(1.950)\end{array}$ & $\begin{array}{r}-3.660 \\
(1.790)\end{array}$ & ** \\
\hline Wealth (in 100,000 of 2004 dollars) & $\begin{array}{l}-0.290 \text { ** } \\
(0.147)\end{array}$ & $\begin{array}{c}-0.439 \\
(0.150)\end{array}$ & $\star \star \star$ \\
\hline Constant & 26.678 & 28.703 & \\
\hline Mean Expected Probability of Working Past 65 & 26.55 & 32.76 & \\
\hline $\begin{array}{l}\mathbf{N} \\
\mathbf{R}^{2}\end{array}$ & $\begin{array}{c}3,963 \\
0.123\end{array}$ & $\begin{array}{c}2,155 \\
0.095\end{array}$ & \\
\hline
\end{tabular}

Source: Authors' estimates, based on data from the HRS.

Note: Weighted OLS regressions on a sample of workers ages 51 to 56 . See table 2 for additional details.

* $p<.10 ; \quad$ ** $p<.05 ; \quad$ *** $p<.01$ 
Table 6. Share of Change in Expected Probability of Working Past Ages 62 and 65 Due to Changes Over Time in Personal Characteristics (\%)

\begin{tabular}{lccccc}
\hline & \multicolumn{2}{c}{ Past 62 } & & \multicolumn{2}{c}{ Past 65 } \\
\cline { 2 - 3 } \cline { 5 - 6 } & $\begin{array}{c}\text { Using 1992 } \\
\text { Coefficients }\end{array}$ & $\begin{array}{c}\text { Using 2004 } \\
\text { Coefficients }\end{array}$ & & $\begin{array}{c}\text { Using 1992 } \\
\text { Coefficients }\end{array}$ & $\begin{array}{c}\text { Using 2004 } \\
\text { Coefficients }\end{array}$ \\
\cline { 2 - 3 } Gender & -11.0 & -11.6 & & -5.4 & -5.3 \\
Marital Status & 6.2 & 7.9 & & 4.7 & 4.0 \\
Educational Attainment & 33.4 & 27.6 & & 21.9 & 12.9 \\
DB Pension Coverage & 19.9 & 22.5 & & 13.2 & -13.2 \\
DC pension Coverage & -10.3 & 9.0 & & -9.1 & -0.9 \\
Retiree Health Insurance Coverage & 46.5 & 30.4 & & 19.8 & 8.7 \\
Earnings & -0.2 & 9.7 & & 3.0 & -4.4 \\
Other Income & -10.3 & -8.9 & & -2.6 & -4.7 \\
Wealth & -8.2 & -12.3 & & -3.7 & \\
\hline
\end{tabular}

Source: Authors' estimates, based on data from the HRS.

Note: The change in self-reported probability due to characteristic $x$ based on 1992 coefficients equals $B_{1992}\left(X_{2004}-X_{2002}\right)$ and the change based on 2004 characteristics equals $\mathrm{B}_{2004}\left(\mathrm{X}_{2004}-\mathrm{X}_{2002}\right)$. 


\section{RECENT WORKING PAPERS FROM THE \\ CENTER FOR RETIREMENT RESEARCH AT BOSTON COLLEGE}

Job Tenure and Pension Coverage

Alicia H. Munnell, Kelly Haverstick, and Geoffrey Sanzenbacher, October 2006

Has the Displacement of Older Workers Increased?

Alicia H. Munnell, Steven Sass, Mauricio Soto, and Natalia Zhivan, September 2006

No Place Like Home: Older Adults and their Housing

Timothy Smeeding, Barbara Boyle Torrey, Jonathan Fisher, David S. Johnson, and Joseph Marchand, August 2006

Effects of Public Policies on the Disposition of Lump-Sum Distributions: Rational and Behavioral Influences

William G. Gale and Michael Dworsky, August 2006

Pensions, Social Security, Wealth and Lifetime Earnings: Evidence from the Health and Retirement Study

William G. Gale and John W.R. Phillips, August 2006

Determinants and Consequences of Bargaining Power in Households

Leora Friedberg and Anthony Webb, June 2006

Earnings and Women's Retirement Security

Alicia H. Munnell and Natalia Zhivan, June 2006

Mortality Heterogeneity and the Distributional Consequences of Mandatory

Annuitization

Guan Gong and Anthony Webb, June 2006

Can Heterogeneity of Populations Explain Differences in Mortality?

James W. Vaupel, Roland Rau, Carlo Giovanni Camarda and Kristin G. von Kistowski, March 2006

Personalized Retirement Advice and Managed Accounts: Who Uses Them and How Does Advice Affect Behavior in 401(k) Plans?

Julie Agnew, March 2006

All working papers are available on the Center for Retirement Research website

(http://www.bc.edu/crr) and can be requested by e-mail (crr@bc.edu) or phone (617-552-1762). 